\title{
TITLE INDEX OF VOLUME 8
}

\section{EDITORIALS}

\section{LETTER TO THE EDITOR}

\section{1, 47, 71, 105 INTERVIEW}

\section{UNITED NATIONS ACTIVITIES}

Senior Level Meeting on Environmental Law

UNCLOS III - Flexibility Prevails (Lee Kimball and Adolf R.H. Schneider)

Draft World Charter for Nature Revised

Protection of the Ozone Layer

World Charter for Nature

World Soil Charter

Draft Convention for Wider Caribbean Region

UN/GA

- Environment Debated

UNEP

- The Coming Sessions: Session of a Special Character

UN/ECE

- Programme and Policy Discussion

\section{OTHER INTERNATIONAL DEVELOPMENTS}

Transfrontier Pollution - Some Problems in the '70's and '80's (Jim W. MacNeill)

IUCN General Assembly

A Look at Some Issues before an Ozone Convention (Rudolf

J. Engelmann)

Antarctica and the Southern Ocean

Red Sea Treaty Signed

IUCN's New Conservation for Development Centre (Michael

J. Cockerell)

Maritime Safety

NATO/CCMS

- Forecasts of Long-Term Developments (Günther Hartkopf)

\section{REGIONAL ACTIVITIES}

EC

- Pollution Marine par les Hydrocarbures (Pascale Kromarek)

- Agreement on Chemicals Control

- The Directive on Environmental Impact Assessment (William

V. Kennedy

- Protection of Birds

EP

- Parliamentary Action

\section{NATIONAL AFFAIRS}

Canada

- Still More Acid Rain?

China

- Energy and Environment in China (Wolfgang K.H. Kinzelbach)

F.R. Germany

- CITES Statistics

France

- Décentralisation et Coopération Transfrontalière (Pascale

Kromarek)

Hungary

- The Control of Water Pollution (Frank B. Wright)

Norway

- "Acid" Report Released

Poland

- Environmental Protection in the People's Republic of Poland (Ludwik Jastrzebski and Alfred Rest)

USA

- A Less Clean Air Act?

- Less Funds for UNEP?

- Return to LOS Negotiations

- Wildlife Broadcasts, via Satellite

- The Rundown of EPA

- LOS
105

Interview with Beate Weber

\section{SELECTED DOCUMENTS}

UN

2 - Conclusions and Recommendations of Montevideo

- Programme for the Development and Periodic Review of Environmental Law

- Draft World Charter for Nature

- Major Elements and Principles of a Convention for the

Protection of the Ozone Layer

UN/GA

- Draft World Charter for Nature

- Resolutions

- Historical Responsibility of States for the Preservation of

$\begin{array}{ll}\text { Nature for Present and Future Generations } & 96 \\ \text { - Draft World Charter for Nature } & 96\end{array}$

- Draft Resolutions

- Problems of Remnants of War

- Session of a Special Character of the Governing Council of the United Nations Environment Programme to be held in 1982

- Implementation in the Sudano-Sahelian Region of the Plan of Action to Combat Desertification

- Study on Financing the Plan of Action to Combat Desertification

- Exchange of Information of Banned Hazardous Chemicals

and Unsafe Pharmaceutical Products

UNEP

112 - Draft Convention for the Protection and Development of the

115 Marine and Coastal Environment of the Wider Caribbean Region 100

FAO

74 - World Soil Charter 62

IUCN

- IUCN General Assembly Resolutions

- World Conservation Strategy 35

- Conservation and Peace $\quad 35$

- Genetic Resources 36

- Tropical Moist Forests 36

- Antarctica Environment and the Southern Ocean 37

- Law of the Sea 38

- Deepsea Mining and Establishment of Protected Areas of the Deep Ocean

- Ramsar Convention

- Environmental Effects of Acid Rain and Snow and Other Acid Depositions

- International Trade in Pesticides

- Antarctica and the Southern Ocean

- Motion for a Resolution

- On the Role of the European Parliament in its Relation with the European Council

- On the Proposal for a Draft Recommendation Concerning the Registration of Work Involving Recombinant Desoxyribonucleic Acid (DNA)

- On Community Trade in Seal Products and in Particular in Products Deriving from the Whitecoat Pups of Harp and Hooded Seals (Pagophilus Groenlandicus and Cystophora Cristata)

- On Europer

Norway

- Acid Precipitation - Effects on Forest and Fish 101

Poland

- Protection and Planning of the Environment 42

USA

- United States Law of the Sea Policy: Fact Sheet (Extracts) 127

- United States Law of the Sea Policy: Statement by the President 127

- The Destruction of EPA (Russell E. Train) 128

Port State Control: Memorandum of Understanding 125 